\title{
Urine Casts
}

National Cancer Institute

\section{Source}

National Cancer Institute. Urine Casts. NCI Thesaurus. Code C38095.

Tubules in the kidneys secrete proteins. Under some circumstances, these proteins precipitate out to form little cylindrical impressions of the tubules called casts. If anything is present in the tubules at the time, it gets trapped in the protein casts. This offers a "snap shot" of the tubular lumen at the time of cast formation. (from Medline Plus) 